$\xi=-1$

\title{
Does service quality of self-checkout technology improve purchasing intention in Malaysia retail industry?
}

\author{
Jia Wen Siah, Soo-Fen Fam* \\ Faculty of Technology Management \& Technopreneurship, Universiti Teknikal Malaysia Melaka \\ *Corresponding author E-mail: famsoofen@utem.edu.my
}

\begin{abstract}
The aim of this research is to determine the factors that affect self-checkout technology service quality and to investigate the relationships among service quality, customer satisfaction and purchasing intention in Malaysian supermarkets. The service quality dimensions include speed, ease of use, reliability, enjoyment and control was adapted from Dabholkar's attribute based model. A questionnaire-based survey was used and data were collected from 394 customers from selected supermarket at Putrajaya. The data were analyzed using multiple regression analysis by IBM-SPSS version 23. All hypothesis formulated in the study were positive significant. The contribution of this study is to provide practical insights into service quality dimensions for managing customer satisfaction and business performance.
\end{abstract}

Keywords: Service Quality; Self-service technology; Self-Checkout; Dabholkar attribute-based model; Multiple Regression; Retailing

\section{Introduction}

The service sector is the largest mainstream in Malaysia GDP, which generates a significant direct and indirect impact on Malaysia GDP. Malaysia retail industry is driven by rising disposable income, consumer confidence and increasing high net worth individuals [1]. A major challenge for Malaysia supermarket industry is to strengthen customer spending power and patronage level with the development of other existing supermarket. As an upper middle class income country and consumer-driven economy in Malaysia, it is important to understand the current spending patterns and behaviors of consumers in the country to understand where the economy is headed and what can be expected from the market [2]. Customer behavior reflects market response as well as the performance of a retail business. Customer satisfaction is of great value to the companies to better serve customers and retain their competitive advantage [3]. Retailers should also be reassured that new technologies present enormous opportunities to foster deeper and more loyal relationships with new and existing customers while hunting for bigger margins as retailers seek to reduce or reallocate staff and cut working hours. The quality of service have to be strengthen with the aid of technology. Self-checkout technology can be a viable solution to cut cost, increase productivity and reach new customer segment [4].

In this study, we examine the self-checkout technology service quality associated with its effect on customer satisfaction and purchasing intention. While most research embraces these channels for their cost-efficiency instead it has not examined how actually the awareness of self-checkout technology being concern and utilize by Malaysian shoppers and whether a shift from personal to self-service affects customer-firm relationships. This study covers all of the supermarket that has implemented self-checkout technology and this will provide the first insight into the self-checkout technology in Malaysia and identify its attributes of service quality delivered by self-checkout technology to enhance the existing pace of the operation by technology thus impending development in retail industry.

\section{Literature Review}

In the tough competition arena in which growing population of middle class, increased income, market reforms, high rate of urbanization, changing lifestyles and mushrooming of modern shopping centers in cities and town, service quality are becoming driving forces of economies currently resulting in much attention on innovation of new services from firms to satisfy customer needs [5]. In Malaysia economy, this industry contributes 54\% of GDP annually. Malaysia retailers have to constantly upgrade with better technologies to keep evolving with the ever-changing needs of the consumers. Technological innovation in retail is now oriented to enhance shoppers' shopping activities as well as retailers' business profitable [6].

Self-service technology adoption has been cited by businesses as a critical element in controlling costs and improving customer experience [7-8]. Self-service technology(SST) can be system in a hardware that service providers offer so that customers can perform the service, or part of the service, by themselves [9]. Selfservice technologies have changed the way of delivering services; consumers not only consume the service, but also actively participate in service delivery [10]. By doing this, consumers can contribute to improved perceived service quality in self-service technology encounters.

A model developed by Dabholkar in 1996 has been used in several studies ${ }^{11}$. Two different models were initially developed and tested for researching service quality within the field of technologybased self-service options which then developed an attribute-based model and an overall affect model ${ }^{11}$. The overall affect model based on affective approach while the attribute-based model had a greater explanatory power of expected service quality based on a cognitive approach to decision making. The attribute based model suggest that five attributes of the service delivery are important to 
potential customers of technology-based self-service options which in turn leads to intention to use the TBSS option. The five attributes include speed, ease of use, reliability, enjoyment, and control [11]. In SST context, speed is considered as speed of transaction by considering the time taken to complete a transaction through SSTs [11]. Hence, SST can be considered as an alternative channel for customers who want to reduce service delivery time [12]. Users prefer to use self-checkout counters when they expect a shorter checkout time at self-checkout counters compared to non-users [8]. According to Dabholkar, the ease of use of a selfservice technology associated with reducing potential social risk and spending less effort ${ }^{11}$. Since people in general are not equipped with the necessary skills and confidence, customers may feel anxious over expected extra efforts in terms of physical and mental exertion which lead them to avoid self-service [12]. The reliability refers to how SST consistently and accurately performs the expected task [13]. The enjoyment is something that intrinsically arises from interacting with a self-service option and control as "the amount of leverage that a customer feels he/she has over the process or outcome" [11].

\subsection{Customer Satisfaction}

Satisfaction is considered to be a customer's summary affective response to the consumption experience [14-16]. Self-service technology (SST) could be an alternative in delivery services [17] it is expected that self-checkout service quality contributes to store service quality by adding benefits, such as saving time and money 18 avoiding service personnel [11,18], and being in control [11]. In this case, satisfaction could be defined that a supermarket has just barely met the customer's expectations, not exceed nor disappointed those expectations. Satisfaction is an indicator of met or exceeded expectations. Customers evaluate their overall service experience at post-purchase stage as satisfaction. Consumers are likely to be satisfied with overall experience if they are satisfied with an SST attributes they consider important [18]. Research on SST demonstrated the positive relationship between service quality and satisfaction [19-22]. Recent research also highlights the importance of identifying service quality that affect customer satisfaction [23].

\subsection{Purchasing Intention}

Purchasing intention is the repeated process of buying goods and services [24]. Numerous literature had studied the relationship between re-purchase intention and perceived quality [25-28]. For example, the high quality of website function has positive relationship with purchase intention [29]. Thus, this study expects that an increase in service quality delivered by self-checkout technology leads to an increase in purchasing intention toward a retail store. Here we intend to investigate the causal relationship between service quality and the intention to purchase more frequently.

\section{Hypothesis and Framework}

Based on the above literature review, the research framework was proposed (Figure 1) and seven hypotheses were formulated:

H1: Speed has positive effect on service quality.

$\mathrm{H} 2$ : Ease of use has positive effect on service quality.

H3: Reliability has positive effect on service quality.

H4: Enjoyment has positive effect on service quality.

H5: Control has positive effect on service quality.

H6: Self-checkout service quality has positive effect on customer satisfaction.

H7: Customer satisfaction has positive effect purchasing intention.

\section{Methodology/Materials}

A structured questionnaire was designed for the research of this paper. A scale comprising 36 items was considered in the study. The items included in the study have been adapted from existing literature and has been further modified and substitute carefully to match with the industry. The constructs in this study such as speed (4 items), ease of use (5 items), reliability ( 5 items), enjoyment ( 5 items), and control (4 items, overall service quality (4 items), customer satisfaction (4 items) and purchasing intention (5 items) were adapted accordingly [11,30-32]. A seven point Likert scale was employed to measure service quality attributes, customer satisfaction and purchasing intention ranging from " 1 - strongly disagree" to "7- strongly agree".

The questionnaires were distributed in the Tesco IOI City, Putrajaya. The selection of the customers was based on the convenient sampling method. An intercept survey was conducted face-to-face with a trained data collector engaging with those that have completed their shopping through the self-checkout lane. The survey process took a quite long period as customers do not like to participate in such survey. The data collection process consumed about 5 weeks which starts in the first week of February 2017 until the first week of March 2017. Data collection was set forth with an initial target of 500 samples. This is to avoid reluctance of participation, rush hour movement and other unexpected situations. A total of 500 consumers was approached and 382 completed questionnaires were obtained.

Multiple linear regression analysis is used to analyze all 6 variables. Speed, ease of use, reliability, enjoyment and control as independent variables while self-checkout technology service quality as dependent variable. This analysis is used to measure the effect of each independent variable to dependent variable. Then, simple correlation coefficient was analysed to verify the relationship between service quality with customer satisfaction and customer satisfaction with purchasing intention. IBM-SPSS version 23.0 was used in this study to analyse the data.

\section{Results and Findings}

\subsection{Respondents' profiles}

Out of 382 responses, $148(38.7 \%)$ were males and $234(61.3 \%)$ were females. The majority $(43 \%)$ of the respondents were aged between 25-34 years old. About 70\% of them were Malay and Chinese and the remaining were Indian and others. One hundred and fifty-one $(39.5 \%)$ respondents were graduated from college. More than $50 \%$ had the knowledge of self-checkout. The finding on customer shopping habits demonstrate a relative high shopping items on household (36\%) and groceries (47\%) and a considerable high rate of visiting 2 or 3 times per week (39\%) and sometimes they will use self-checkout.(56\%)

\subsection{Reliability analysis}

The internal consistency reliabilities of scales are demonstrated by calculating the coefficient alpha of Cronbach alpha (Table 1). The Cronbach alpha value is more than 0.70 indicating that items used to measure the constructs are reliable and satisfactory (33).

\subsection{Regression analysis}

This paper aims to explain to what extent self-checkout technology service quality (dependent variable) is explained by speed, ease of use, reliability, enjoyment and control. Based on the Model Summary (Table 2), the result reports that the $\mathrm{R}$ value (correlation coefficient) between independents variables and dependent variable is 0.933 which indicates a positive good correlation. This means that the consumers are concerned on the factors that affect the service quality delivered by self-checkout technology. The $\mathrm{R}$ 
square is equal to 0.871 which means that $87 \%$ of the selfcheckout technology service quality is explained by the independent variables. In other word, speed, ease of use, reliability, enjoyment and control contribute $87 \%$ to affect the self-checkout technology service quality. For the ANOVA test analysis in (Table 3), the significant level, $p<0.01$ which indicates a $1 \%$ level of confidence for this result. In simple word, it means that it was only a $1 \%$ risk of concluding that a difference exists in the result. From the coefficient analysis (Table 4), the results indicated that the significant level below 0.05 are speed, ease of use, reliability, enjoyment and control which means that these five variables has significant contribution to the service quality delivered by selfcheckout technology. Beta coefficient explained which variables are important factors in the model by looking at the largest value derived. Reliability $(\beta=0.293, p=0.000)$ is the most significant, followed by ease of use $(\beta=0.292, p=0.000)$, speed $(\beta=-0.113$, $p=0.000)$, control $(\beta=-0.100, p=0.037)$ and enjoyment $(\beta=0.071$, $\mathrm{p}=0.044$ ). The result lends support to $\mathrm{H} 1, \mathrm{H} 2, \mathrm{H} 3, \mathrm{H} 4$ and $\mathrm{H} 5$.

Table 5,6 and 7 link the service quality with customer satisfaction. The result of regression analysis shows that service quality contribute significantly $(\mathrm{p}<0.01)$ and predicts $38 \%$ of the variation in customer satisfaction. The relationship between service quality and customer satisfaction proves to be significant and considered strong correlation $(\mathrm{R}=0.62)$. Thus, $\mathrm{H} 6$ is supported.

Table 8,9 and 10 link the service quality with customer satisfaction. The result of regression analysis shows that customer satisfaction contribute significantly $(\mathrm{p}<0.01)$ and predicts $35 \%$ of the variation in purchasing intention. The relationship between customer satisfaction and purchasing intention proves to be significant and considered strong correlation $(\mathrm{R}=0.59)$. Thus, $\mathrm{H} 7$ is supported.

The analysis reveals that all hypothesis are accepted. The results highlights that speed, ease of use, reliability, enjoyment and control are the driver that affects self-checkout technology service quality. This finding helps retailers to know the important factors of service quality delivered by self-checkout technology through customer evaluation.

\section{Conclusion}

The aim of this research is to find the factors of service quality on self-checkout technology. Based on the findings, the five drivers of service quality, namely speed, ease of use, reliability, enjoyment and control would allow customers to assess the service quality of self-checkout technology in Malaysia supermarket. The result from the analysis confirms that Dabholkar's based model is still appropriate in measuring service quality for self-service technology and also suitable in measuring quality in the supermarket. Reliability is the most influential factors in measuring service quality of self-checkout technology, followed by ease of use, speed, control and enjoyment. This is probably due to the majority of the respondents are within the aged ranged 25 to 34 and are either housewife or working adults. This type of respondents have busy lifestyle, so their shopping habits are more to household and groceries. Therefore, they concern on the reliable of the technology. If the technology is reliable, they can easily adapt and utilize the benefits of using self-checkout technology. This result consistent with previous literature (34). The study also reveals that service quality factors will significantly exert an influence on customer satisfaction. Furthermore, this study explored the positive and significant relationship between customer satisfaction and purchasing intention. The contribution of this study is to focus on real-life scenario and interpreting the current situation of newly implemented self-service technology in supermarket. Retailers can use the result of this to consider self-checkout technology implementation. The self-service technology provider can also use this scheme to enhance the reliability of the self-checkout machine to meet the standard of service quality for Malaysia customers.

\subsection{Limitation and Future Research}

The limitation of this research is the location of the survey. The convenient sample was collected from a single supermarket in Malaysia. Therefore, it could not be generalized and represented for the whole population in Malaysia. It was suggested to cover all the supermarkets in Malaysia that implemented self-checkout technology. The extended research for this study could cover another supermarket that installed self-checkout technology which is at Tesco KSL City, Johor Bahru to represent the whole population of this study. Second, there are many other factors influencing customer satisfaction and purchasing intention. The model of this study explained $35-38 \%$ of the variance in addressing the variation between service quality with customer satisfaction and customer satisfaction with purchasing intention. Future research should investigate external factors such as gender and demographic to improve the model.

\section{References}

[1] Euromonitor. Retailing in Malaysia. Passport, (April), 9. (2015)

[2] K. B. Ooi, J. J. Sim, K. T. Yew and B. Lin. Computer Human Behavior. 27, 1168-1178. (2011)

[3] B. Ranjbarian, A. Sanayei, M.R. Kaboli and A. Hadadian International Journal of Business Management. 7, 40-48. (2012).

[4] F. Demirci Orel and A. Kara. Journal of Retailing and Consumer Service. 21, 118-129. (2014a)

[5] H. Cho, S. Fiorito and S.Symphonya. Emerging Issue of Management, 43-55. (2010).

[6] E. Pantano and M. Viassone. Journal of Retailing and Consumer Service. 21, 43-47. (2014)

[7] W. Chih-Hung. Managing Service Quality: An International Journal, 22, 128-144. (2012)

[8] H.K. Leng and K.N.L. Wee. The International Review of Retail, Distribution and Consumer Research, 27, 94-108. (2017)

[9] P.A Dabholkar, Journal of Consumer Research, 21, 100. (1994)

[10] G.L. Marzocchi and A. Zammit. The Service Industries Journal, 26(6), 651-669. (2006)

[11] P.A Dabholkar. International Journal of Research in Marketing, 13(1), 29-51. (1996)

[12] H.J. Lee and K.J. Yang. Retail Consumer Service, 20(1), 51-57. (2013)

[13] B. Weijters, D. Rangarajan, T.Falk and N. Schillewaert. Journal of Service Research (Vol. 10). (2007)

[14] N.K. Aliman and W.N. Mohamad. Procedia - Social and Behavioral Sciences, 224(August 2015), 141-148. (2016)

[15] R.L. Oliver. Journal of Marketing Research. 17, 460-469. (1980)

[16] S.O. Olsen. Journal of the Academy of Marketing Science. 30, 240249. (2002)

[17] J. Rowley and F. Slack. International Journal of Retail \& Distribution Management. 31, 329-339. (2003)

[18] M.L. Meuter, A.L. Ostrom, R.I. Roundtree and M.J. Bitner. Journal of Marketing. 50, 50-64. (2000)

[19] P.A. Dabholkar and B. Spaid. The Service Industries Journal. 32 1415-1432. (2012)

[20] F. Demirci Orel and A. Kara. Journal of Retailing and Consumer Services. 21, 118-129.(2014b)

[21] Y.F. Kuo, C.M. Wu and W.J. Deng. Computers in Human Behavior. 25, 887-896. (2009)

[22] J.S.C. Lin and P.L. Hsieh. Computers in Human Behavior. 23, 15971615. (2007)

[23] S. Dolnicar, T. Coltman and R. Sharma. Journal of Travel Research. 54, 152-178. (2013)

[24] T. Jiradilok, S. Malisuwan, N. Madan and J. Sivaraks. Journal of Economics, Business and Management, 2, 5-11. (2014)

[25] K. Alexandris, N. Dimitriadis and D. Markata, Managing Service Quality.12, 224-231 (2002)

J.J. Cronin and S.A. Taylor. Journal of Marketing, 56, 55. (1992)

D.-H. Park, J. Lee and I. Han. International Journal of Electronic Commerce. 11, 125-148. (2007)

[28] A.R. de A. Silva, A.S. Bioto, P. Efraim and G. de C Queiroz. Journal of Cleaner Production, 141, 11-21. (2017)

[29] Y-F. Kuo. Total Quality Management and Business Excellence, 14 461-473. (2003)

[30] M. Chandrashekaran, K. Rotte, S.S.Tax and R. Grewal. Journal of Marketing Research, 44, 153-163. (2007)

[31] N. Seth, S.G. Deshmukh and P. Vart. International Journal of 
Quality \& Reliability Management. 22. (2005)

[32] S.A. Taylor and T.L. Baker. Journal of Retailing, 70, 163-178. (1994)

[33] U. Sekaran and R. Bougie. Research Methods for Business. In
Research methods for business. 436. (2013)

[34] 34. S. Fam, N,A. Othman, J.W. Siah and H. Musa, H. Universiti Teknikal Malaysia Melaka. Proceedings of Mechanical Engineering Research Day 2017. (2017) March; Melaka, Malaysia.

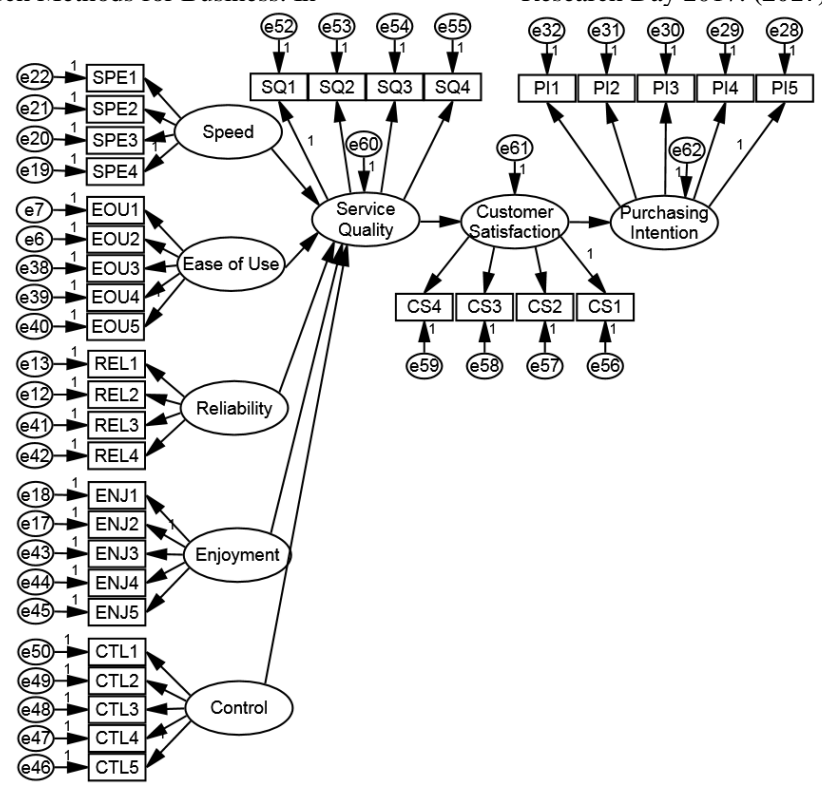

Fig 1:. Research Model

Authors: Jia Wen Siaha ${ }^{\text {a }}$, Soo-Fen Fam

Manuscript Title: Does Service Quality of Self-Checkout Technology Improve Purchasing Intention in Malaysia Retail Industry?

Table 1: Result of reliability analysis

\begin{tabular}{|l|c|r|}
\hline Variables & Items & Cronbach's alpha \\
\hline Speed & 4 & 0.926 \\
\hline Ease of Use & 5 & 0.939 \\
\hline Reliability & 4 & 0.932 \\
\hline Enjoyment & 5 & 0.821 \\
\hline Control & 5 & 0.959 \\
\hline Service Quality & 4 & 0.832 \\
\hline Customer Satisfaction & 4 & 0.936 \\
\hline Purchasing Intention & 5 & 0.946 \\
\hline
\end{tabular}

Table 2: Model Summary

\begin{tabular}{|c|c|c|c|c|}
\hline Model & $\mathbf{R}$ & R Square & Adjusted R Square & $\begin{array}{c}\text { Std. Error of the Esti- } \\
\text { mate }\end{array}$ \\
\hline
\end{tabular}

Table 3: ANOVA

\begin{tabular}{|c|c|c|c|c|c|c|}
\hline \multirow{2}{*}{\multicolumn{2}{|c|}{ Model }} & \multicolumn{5}{|c|}{ 年 } \\
\hline & & Sum of Squares & df & Mean Square & $\mathbf{F}$ & Sig. \\
\hline 1 & Residual & 124.957 & 378 & .331 & & \\
\hline \multicolumn{7}{|c|}{ a. Dependent Variable: Service quality } \\
\hline \multicolumn{7}{|c|}{ b. Predictors: (Constant), Control, Reliability, Ease of Use, Enjoyment, Speed } \\
\hline
\end{tabular}

Table 4: Coefficient Table

\begin{tabular}{|c|c|c|c|c|c|c|}
\hline \multirow{2}{*}{\multicolumn{2}{|c|}{ Model }} & \multicolumn{2}{|c|}{ Unstandardized Coefficients } & \multirow{2}{*}{$\begin{array}{c}\text { Standardized Coefficients } \\
\text { Beta }\end{array}$} & \multirow{2}{*}{$\mathbf{T}$} & \multirow{2}{*}{ Sig. } \\
\hline & & B & Std. Error & & & \\
\hline \multirow{6}{*}{1} & (Constant) & 1.021 & 0.146 & & 6.973 & 0.000 \\
\hline & Speed & 0.113 & 0.029 & 0.142 & 3.873 & 0.000 \\
\hline & Ease of Use & 0.292 & 0.046 & 0.323 & 6.414 & 0.000 \\
\hline & Reliability & 0.293 & 0.041 & 0.335 & 7.225 & 0.000 \\
\hline & Enjoyment & 0.071 & 0.035 & 0.085 & 2.017 & 0.044 \\
\hline & Control & 0.100 & 0.048 & 0.106 & 2.094 & 0.037 \\
\hline
\end{tabular}

Table 5: Model Summary

\begin{tabular}{|c|c|c|c|c|}
\hline Model & $\mathbf{R}$ & R Square & Adjusted R Square & $\begin{array}{l}\text { Std. Error of the Esti- } \\
\text { mate }\end{array}$ \\
\hline 1 & $.616^{\mathrm{a}}$ & 0.380 & 0.378 & 1.267 \\
\hline
\end{tabular}




\begin{tabular}{|c|c|c|c|c|c|c|}
\hline \multicolumn{7}{|c|}{ Table 6: ANOVA } \\
\hline Mode & & Sum of Squares & Df & Mean Square & $\mathbf{F}$ & Sig. \\
\hline \multirow{3}{*}{1} & Regression & 375.313 & 1 & 375.313 & 233.921 & $.000^{\mathrm{b}}$ \\
\hline & Residual & 612.898 & 382 & 1.604 & & \\
\hline & Total & 988.211 & 383 & & & \\
\hline \multicolumn{7}{|c|}{ a. Dependent Variable: Customer Satisfaction } \\
\hline \multicolumn{7}{|c|}{ b. Predictors: (Constant), Service quality } \\
\hline
\end{tabular}

Table 7: Coefficient Table

\begin{tabular}{|c|c|c|c|c|c|c|}
\hline \multirow{2}{*}{\multicolumn{2}{|c|}{ Model }} & \multicolumn{2}{|c|}{ Unstandardized Coefficients } & \multirow{2}{*}{$\begin{array}{c}\text { Standardized Coefficients } \\
\text { Beta } \\
\end{array}$} & \multirow{2}{*}{$\mathbf{t}$} & \multirow{2}{*}{ Sig. } \\
\hline & & B & Std. Error & & & \\
\hline \multirow{2}{*}{1} & (Constant) & 3.052 & 0.331 & & 9.224 & 0.000 \\
\hline & Service Quality & 0.623 & 0.041 & 0.616 & 15.294 & 0.000 \\
\hline
\end{tabular}

Table 8: Model Summary

\begin{tabular}{|c|c|c|c|c|}
\hline Model & $\mathbf{R}$ & R Square & Adjusted R Square & $\begin{array}{l}\text { Std. Error of the Esti- } \\
\text { mate }\end{array}$ \\
\hline $\begin{array}{ll} & 1 \\
\end{array}$ & $.592^{\mathrm{a}}$ & 0.351 & 0.349 & 1.264 \\
\hline
\end{tabular}

Table 9: ANOVA

\begin{tabular}{|c|c|c|c|c|c|c|}
\hline Mode & & Sum of Squares & Df & Mean Square & $\mathbf{F}$ & Sig. \\
\hline \multirow{3}{*}{1} & Regression & 329.324 & 1 & 329.324 & 206.158 & $.000^{\mathrm{b}}$ \\
\hline & Residual & 610.220 & 382 & 1.597 & & \\
\hline & Total & 939.544 & 383 & & & \\
\hline \multicolumn{7}{|c|}{ a. Dependent Variable: Purchasing Intention } \\
\hline \multicolumn{7}{|c|}{ b. Predictors: (Constant), Customer Satisfaction } \\
\hline
\end{tabular}

Table 10: Coefficient Table

\begin{tabular}{|c|c|c|c|c|c|c|}
\hline \multirow{2}{*}{\multicolumn{2}{|c|}{ Model }} & \multicolumn{2}{|c|}{ Unstandardized Coefficients } & \multirow{2}{*}{$\begin{array}{c}\text { Standardized Coefficients } \\
\text { Beta } \\
\end{array}$} & \multirow{2}{*}{$\mathbf{t}$} & \multirow{2}{*}{ Sig. } \\
\hline & & B & Std. Error & & & \\
\hline \multirow{2}{*}{1} & (Constant) & 3.336 & 0.329 & & 10.151 & 0.000 \\
\hline & Service Quality & 0.577 & 0.040 & 0.592 & 14.358 & 0.000 \\
\hline
\end{tabular}

